\title{
OPEN Joint integrity evaluation of laser beam welded additive manufactured Ti6Al4V sheets
}

\author{
P. O. Omoniyi $i^{1,2 \bowtie}$, R. M. Mahamood ${ }^{1,3}$, N. Arthur ${ }^{4}$, S. Pityana ${ }^{4}$, S. Skhosane ${ }^{4}$, Y. Okamoto ${ }^{5}$, \\ T. Shinonaga ${ }^{5}$, M. R. Maina ${ }^{6}$, T. C. Jen ${ }^{1}$ \& E. T. Akinlabi ${ }^{1,7}$
}

The feasibility of joining laser metal deposited Ti6Al4V sheets using laser beam welding was investigated in this article. The additive manufactured sheets were joined using a $3 \mathrm{~kW}$ CWYLS2000-TR ytterbium laser system. The mechanical properties and microstructure of the welded additive manufactured parts (AM welds) were compared with those of the wrought sheets welded using the same laser process. The welds were characterized and compared in terms of bead geometry, microhardness, tensile strength, fractography, and microstructure. The differences in characteristics are majorly found in the width of the bead and tensile strength. The bead width of AM welds appear wider than the wrought welds, and the wrought welds exhibited higher tensile strength and ductility than the AM welds.

The commencement of the fourth industrial revolution (4IR) has seen the growth of additive manufacturing (AM) or 3D printing skyrocket. AM applies 3D design data set to form a layer-by-layer deposition of material ${ }^{\text {; }}$; it is of great advantage over traditional and non-traditional machining techniques involving material removal. AM process results in less material wastage, as high power sources melt the powder to form three dimensional (3D) objects ${ }^{2}$. The AM technique also facilitates easy repair of components flexible fabrication of intricate and complicated shapes. Despite the numerous advantages of AM processes, it also has some limitations, such as confined build chamber size, which might not accommodate large parts production, and poor surface finish of product $^{3,4}$. These limitations, therefore, brought about producing parts in smaller sizes and afterward joining them using fusion welding.

Laser metal deposition (LMD) is an AM process and a near-net-shape technology used to produce solid components. The process involves charging metallic powder or wire, which is melted by laser to form a melt pool, which then solidifies to form a metal deposit ${ }^{2}$. According to Segerstark et al. ${ }^{5}$, LMD can be categorized based on the feedstock used during manufacturing; powder and wire are the feedstocks used generally in LMD. In powder LMD (LMD-P), the powder is blown coaxially along with the inert gas into the melt pool, which might be argon or helium or a combination of both gases in most cases. On the other hand, wire is fed into the melt pool to create LMD-W $\mathrm{W}^{6}$. Indeed, LMD has been helpful in the manufacturing industry. The aerospace industry has achieved an excellent buy-to-fly ratio with the LMD process, and the repair of components has also been achieved ${ }^{7,8}$. Titanium and its alloys have also been beneficial in the fourth industrial revolutionized industries due to its lightweight to strength ratio and excellent corrosion resistivity ${ }^{9}$. The aerospace industry has used titanium and its alloys to design and manufacture fuselage, turbine blades, shafts, and wings. Also, due to its biocompatibility, it is used as surgical materials and implants ${ }^{10}$.

Works of literature are limited on the mechanical and microstructural behavior of Ti6Al4V AM welds. Tavlovich et al. ${ }^{11}$ studied the mechanical and microstructural properties of AM welds using laser beam welding (LBW) and electron beam welding (EBW). The Ti6Al4V additive manufactured products were manufactured using selective laser melting (SLM) process. The AM welds were compared with wrought welds of Ti6Al4V in terms of tensile strength, weld bead profile, and microhardness. The boundaries of the fusion zone (FZ) were

\footnotetext{
${ }^{1}$ Mechanical Engineering Science Department, University of Johannesburg, P. O. Box 524, Johannesburg, South Africa. ${ }^{2}$ Mechanical Engineering Department, University of Ilorin, P. M. B. 1515, Ilorin, Nigeria. ${ }^{3}$ Department of Materials and Metallurgical Engineering, University of Ilorin, P. M. B. 1515, Ilorin, Nigeria. ${ }^{4}$ National Laser Centre, CSIR, P. O. Box 395, Pretoria, South Africa. ${ }^{5}$ Graduate School of Natural Science and Technology, Okayama University, Okayama, Japan. ${ }^{6}$ Department of Mechatronics Engineering, Jomo Kenyatta University of Agriculture and Technology, 62000-00200 Nairobi, Kenya. ${ }^{7}$ Pan Africa University for Life and Earth Sciences Institute, 200132 Ibadan, Nigeria. ${ }^{\boxplus}$ email: omoniyi.po@unilorin.edu.ng
} 


\begin{tabular}{|l|l|l|l|l|l|r|l|l|l|l|}
\hline & Element & Ti & Al & V & C & Fe & N & O & H & Others \\
\hline Wrought Ti6Al4V & Weight (\%) & Remainder & 6.10 & 4.0 & 0.03 & 0.15 & 0.018 & 0.13 & 0.002 & Each $<0.10$ \\
\hline Powder Ti6Al4V & Weight (\%) & Remainder & 6.44 & 4.06 & 0.01 & $<0.01$ & 0.02 & 0.10 & 0.002 & Each $<0.10$ \\
\hline
\end{tabular}

Table 1. Elemental composition of wrought sheet and powder Ti6Al4V.

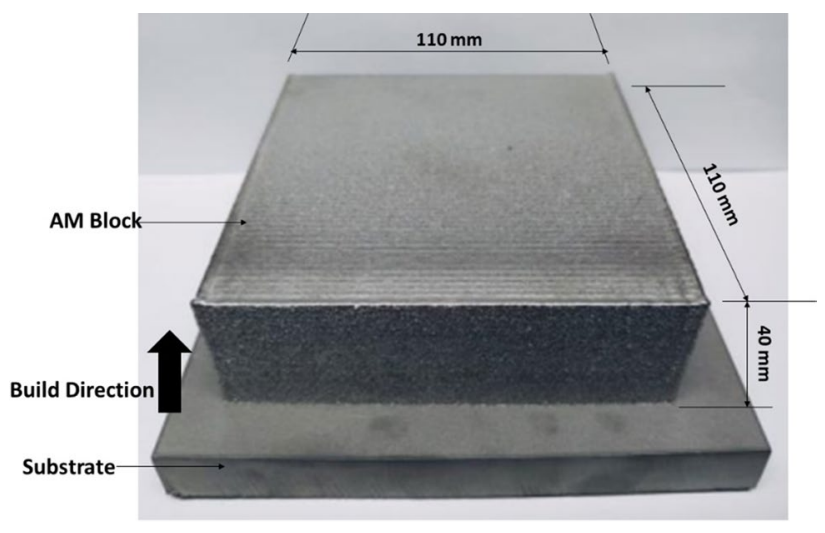

Figure 1. Additive manufactured product test specimen.

reported to be the significant difference between the welding techniques. The FZ of AM welds were wider and appeared to be straight compared to wrought sheets that show an hourglass shape.

In their research, Sun et al. ${ }^{12}$ used laser welding to join electron beam melting (EBM) manufactured Ti6Al4V product to wrought Ti6Al4V, the effect of welding angle on the mechanical properties and microstructure were studied. The microhardness measured was generally influenced by the local microstructure. The tensile strength was greatly affected by the base material (BM) of the additive manufactured product due to the defects developed primarily during the EBM process. Welding angle was observed to have an insignificant effect on the tensile properties of the welds. Conversely, there was a reduction in elongation as the welding angle reduced from 0 to $45^{\circ}$. Similar to the observations of Sun et al. ${ }^{12}$, porosities and non-isotropic properties are significant characteristics of AM parts that contribute significantly to the mechanical strength of AM welds. Besides, increasing energy per unit weld length is required to obtain a keyhole weld for AM welds compared to wrought Ti6Al4V welds ${ }^{13}$. Works of literature have also shown that the tensile strength of the AM welds is greatly affected by the additive manufacturing process. Titanium and its alloys are highly sensitive to atmospheric gases such as nitrogen and oxygen at a temperature of $350^{\circ} \mathrm{C}$ and above ${ }^{14}$. These contaminations caused by atmospheric gases have been reported to affect the microstructure of welds. Coarse columnar grains and $\alpha$ ' martensitic microstructure have been reported to be responsible for brittleness, high microhardness, and reduced ductility ${ }^{15}$. Therefore, the ductility and toughness of welds and additive manufactured products can be improved through heat treatment ${ }^{11,16}$.

Laser welding (LW) is preferred in areas where high strength is required, such as the marine and aerospace industries. The smaller area of the weld zone (WZ) as a result of low heat input and high welding speed, compared to other fusion welding techniques such as metal inert gas (MIG) welding and tungsten inert gas (TIG) welding has made it advantageous ${ }^{15,17}$. Even though Ti6Al4V additive manufactured parts have been welded using different fusion processes as reviewed, the parameter selection has not achieved full penetration in some cases. Therefore, this study aims to substantiate the impact of laser power and welding speed on AM welds' mechanical properties and microstructure. The additive manufactured products were welded using laser welding, and the results were compared to wrought sheets welded using the same welding technique and parameters. All welds were joined in the butt arrangement.

\section{Materials and methods}

The wrought Ti6Al4V (grade 5) sheets used in this research were supplied by Saetra (PTY) Limited, Pretoria, South Africa, in mill annealed state. The dimension is $100 \mathrm{~mm} \times 60 \mathrm{~mm} \times 2 \mathrm{~mm}$, and chemical composition in accordance with ASTM B265 ${ }^{18}$ is shown in Table 1 . The Ti6Al4V (grade 5) powder $45-90 \mu \mathrm{m}$ and chemical composition in accordance with ASTM B $215^{19}$ was supplied by WearTech (PTY) Limited, South Africa. The additive manufactured product (LMD) shown in Fig. 1 was built using Optomec 850-R LENS system, available at laser center of the council of scientific and industrial research (CSIR), Pretoria, with laser power of $400 \mathrm{~W}$, powder feed rate of $2.4 \mathrm{~g} / \mathrm{min}$, hatch spacing of $0.9652 \mathrm{~mm}$, and scanning rotated at $90^{\circ}$ between successive layers. The AM block was then cut into thicknesses of $2 \mathrm{~mm}$ using wire electrical discharge machining (EDM).

Laser welding of parts. The faying sides of the materials were cleaned with acetone to remove impurities before welding. $3 \mathrm{~kW}$ CW YLS-2000-TR ytterbium laser system available at laser center CSIR, Pretoria was 

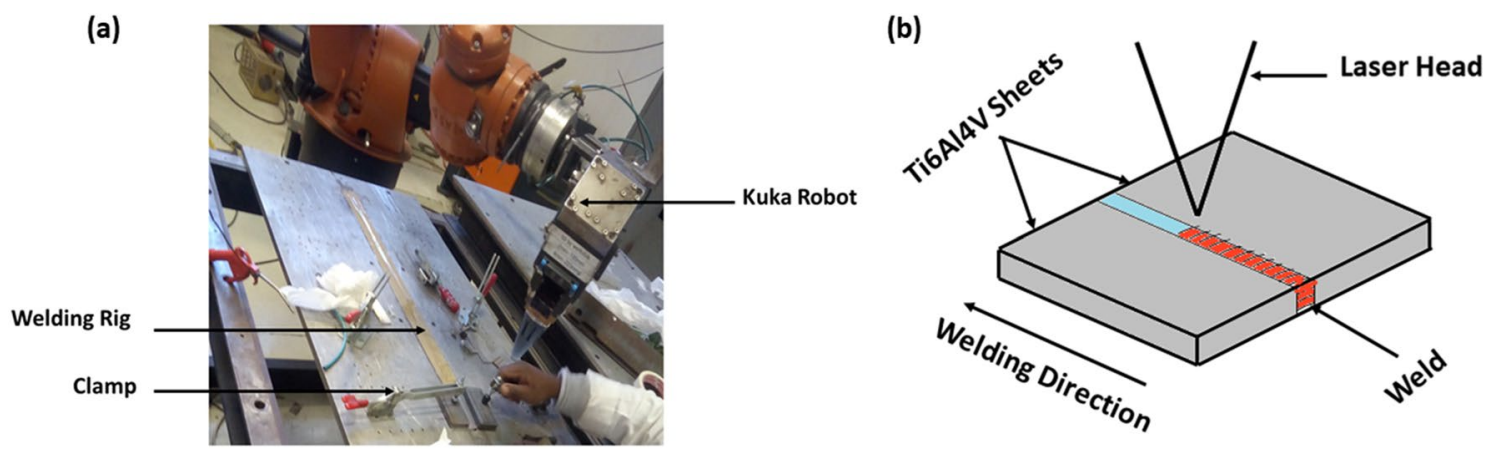

Figure 2. (a) Experimental setup, (b) schematics of the experimental setup.

\begin{tabular}{|l|l|l|l|}
\hline S/N & Laser power $(\mathbf{k W})$ & Welding speed $(\mathbf{m} / \mathbf{m i n})$ & Energy input $(\mathbf{J} / \mathbf{m m})$ \\
\hline L21, AM21 & 2.8 & 2.8 & 60.00 \\
\hline L22, AM22 & 2.8 & 2.6 & 64.62 \\
\hline L23, AM23 & 2.7 & 2.8 & 57.86 \\
\hline L24, AM24 & 2.7 & 2.6 & 62.31 \\
\hline
\end{tabular}

Table 2. Experimental process parameters. ${ }^{\star} \mathrm{L}$ denotes wrought laser welds, AM denotes AM welds.

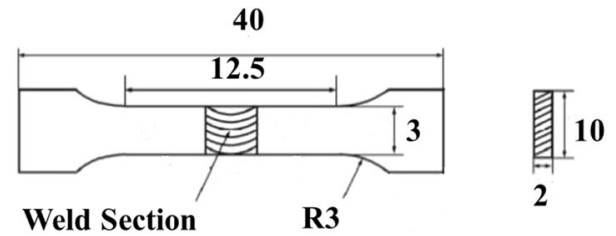

Figure 3. Miniature tensile specimen for AM welds.

employed in welding the parts autogenously. A special welding rig was also employed, with the ability to back purge to prevent contamination of the weld, as shown in Fig. $2 \mathrm{a}$ and the schematics of laser welding in Fig. $2 \mathrm{~b}$. The shielding gas used was argon with a flow rate of $15 \mathrm{~L} / \mathrm{min}$. The same welding parameters used for welding the wrought sheets and the AM products are presented in Table 2.

The energy input is calculated using equation $(1)^{3}$.

$$
E=\frac{P}{v}
$$

where: Energy input $E(\mathrm{~J} / \mathrm{mm})$, Laser Power $P($ Watt), Welding speed $v(\mathrm{~mm} / \mathrm{s})$.

Sample preparation and characterizations. Samples measuring $25 \mathrm{~mm} \times 10 \mathrm{~mm} \times 2 \mathrm{~mm}$ were cut out of the welded sheets across the welds. Each sample was mounted on thermoset resins then the grinding was done using SiC papers (\#320-\#1200). They were further polished till a mirror surface was achieved ASTM E3 ${ }^{20}$. Kroll's reagent was used in etching the surface of the weld for 18 seconds, in accordance with ASTM E407 ${ }^{21}$.

Olympus DP25 Optical Microscope (Olympus Corporation, Japan) was used in capturing the microstructures at the base metal (BM), fusion zone (FZ), and the heat affected zone (HAZ). The tensile samples were cut into ASTM E $8^{22}$ subsize for the wrought welds, and a miniature size shown in Fig. $3^{23}$ was used for the AM welds. Each test sample was pulled using a universal testing machine (UTM) Zwick Roell 2250. TESCAN scanning electron microscopy equipped with energy dispersive spectroscopy (SEM-EDS), available at the University of Johannesburg was used to capture the fractured surface after the tensile test. Indentec Digital Vickers microhardness tester (Indentec, England) at a load of $4.9 \mathrm{~N}$ and dwell time of $15 \mathrm{~s}$, ASTM E384 ${ }^{24}$, was used in profiling the microhardness across the weld.

\section{Results and discussion}

Weld bead geometry. The bead geometry was captured using Olympus SZX16 (Olympus Corporation, Japan) macroscope, and stream essentials software was used in measuring the geometry. The weld shape at the fusion zone (FZ) for both the AM and wrought welds appears to have an hourglass shape and full penetration. Furthermore, the cross-section of the AM welds shown in Fig. 4 reveals a wider width of FZ than the wrought welds in Fig. 5, with the average width of AM weld measuring $1426.94 \mu \mathrm{m}$ and that of wrought welds is 1167.93 


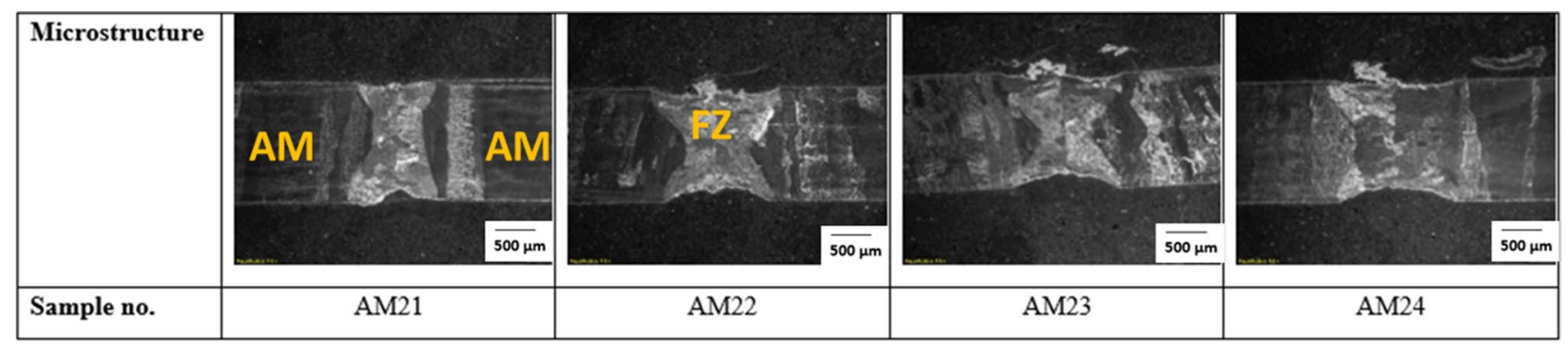

Figure 4. Cross-section of AM welds.

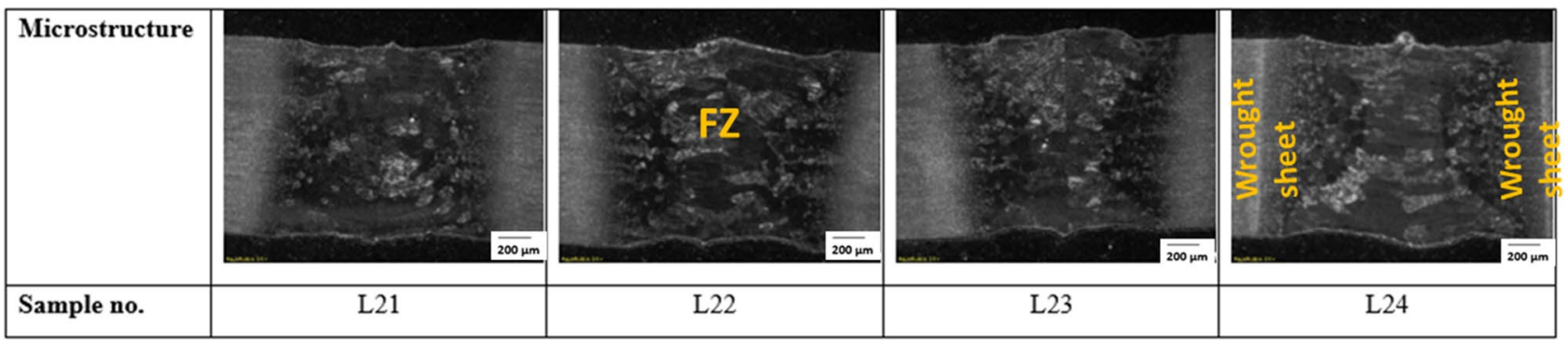

Figure 5. Cross-section of wrought welds.

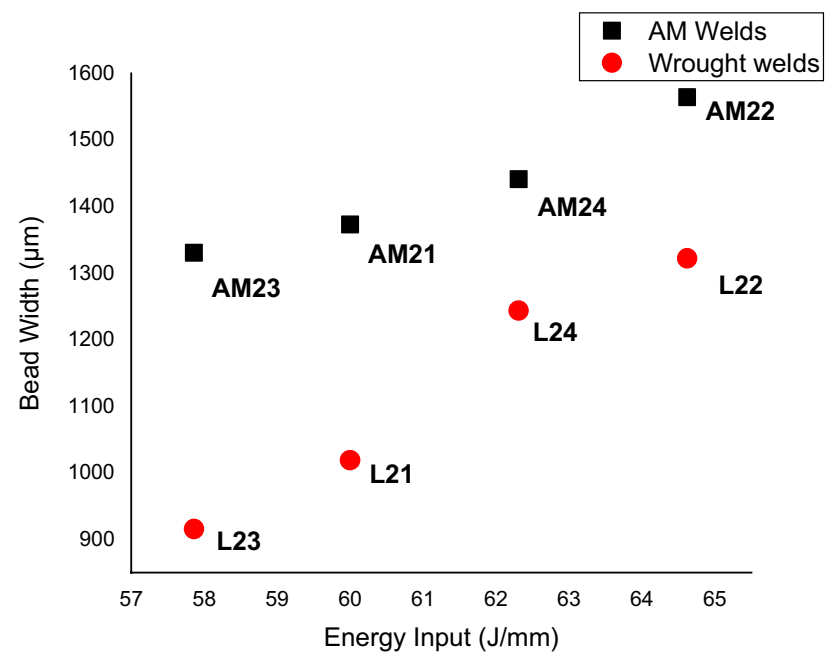

Figure 6. Bead width versus energy input during welding.

$\mu \mathrm{m}$. The increase in the width of the AM welds could be attributed to the possibility of quicker heat transfer within the AM material because of the higher thermal conductivity of AM material over wrought material. Tavlovich et al. ${ }^{11}$ observed the thermal conductivity of AM material to be 2.5 times that of the wrought material, even up to $800^{\circ} \mathrm{C}$. Energy input also significantly affects the bead width of both the AM and wrought welds, with higher energy input resulting in an increased bead width for all welds, as shown in Fig. 6.

Microstructure. The microstructure of the additive manufactured products is made of the layer-by-layer structure coarse columnar grains of an average length of $85.1 \mu \mathrm{m}$, arranged in a sequence of needle-like martensitic $\alpha$ and fine equiaxed grains as also observed by ${ }^{25-27}$ shown in Fig. $7 \mathrm{a}$. The average width of the layer of the columnar grains is $\sim 0.11 \mathrm{~mm}$, and they are as high as the thickness of the material ${ }^{28,29}$. Furthermore, coarse columnar grains with an average length of $49.5 \mu \mathrm{m}$ exist within the FZ, as shown in Fig. $7 \mathrm{~b}$, as a result of cooling from the $\beta$ phase at a rapid rate above the critical cooling rate of $410{ }^{\circ} \mathrm{C} / \mathrm{s}^{30,31}$. The shorter length of columnar grains at the fusion zone (FZ), observed after laser welding, is due to increased heat input. Li et al. ${ }^{32}$ explained that increasing heat input on existing columnar grains results in a shorter length of the columnar grains. The heat affected zone (HAZ) in Fig. $7 \mathrm{c}$ is made of fine equiaxed grains, which may be due to a reduced temperature below the $\beta$ transus temperature of $995^{\circ} \mathrm{C}$ and a faster cooling rate as a result of lower temperature. Yung et al. ${ }^{33}$ 


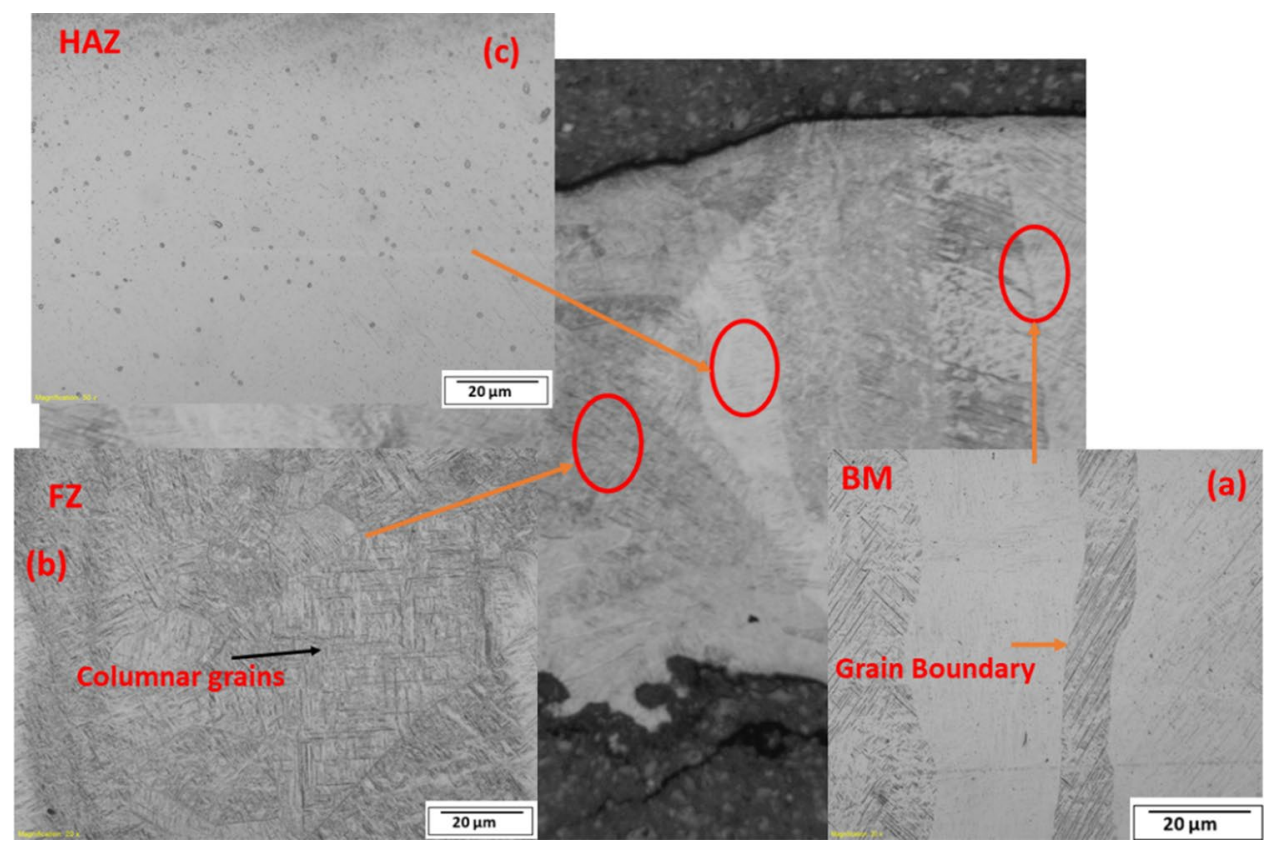

Figure 7. Microstructure of AM welds showing (a) base metal, (b) fusion zone, (c) heat affected zone.

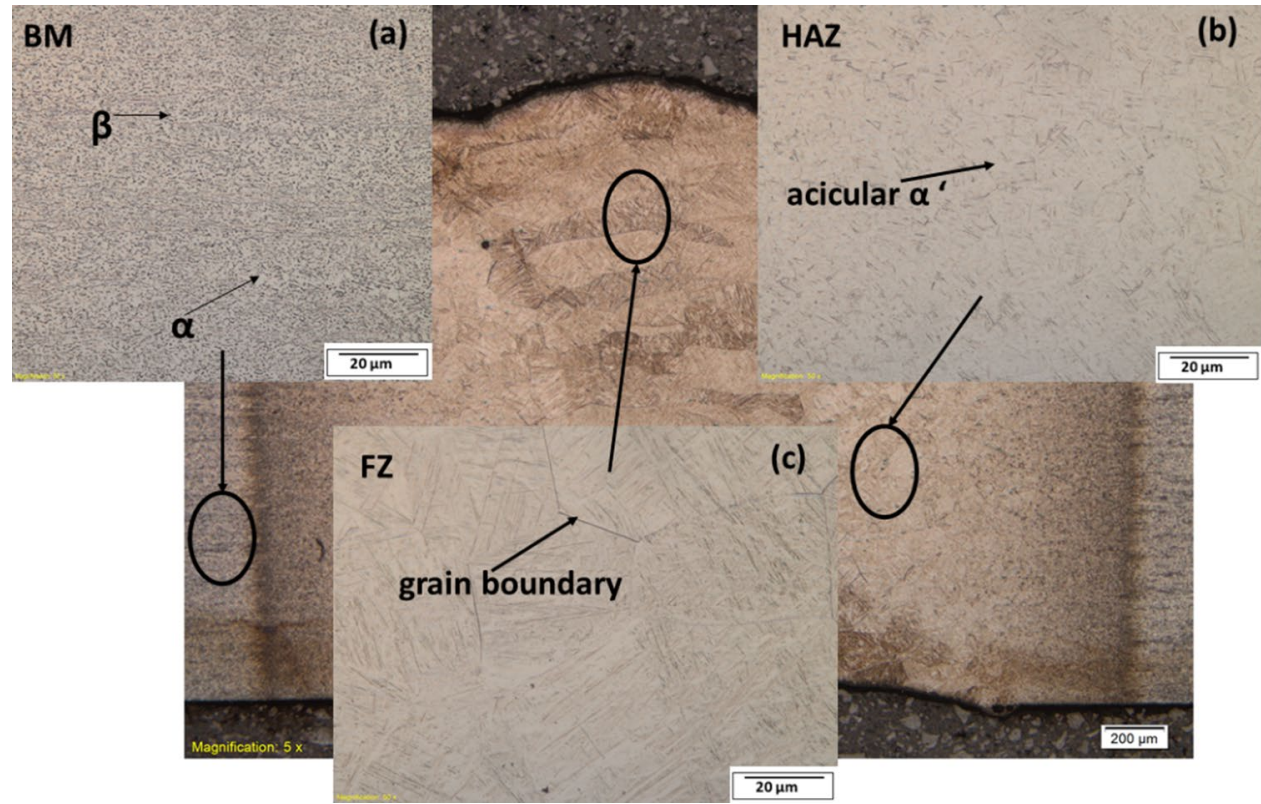

Figure 8. Microstructure of wrought welds showing (a) base metal, (b) heat affected zone, (c) fusion zone.

also observed that the lower temperature causes aging of the martensitic microstructure, turning it into fine $a$ particles.

The BM of the wrought material in Fig. 8a comprises the equiaxed $\alpha$ and $\beta$ phases with an average grain size of $0.68 \mu \mathrm{m}^{6,14,34}$. The HAZ in Fig. $8 \mathrm{~b}$ majorly comprises blocky $\alpha$ and some untransformed $\beta$ and $\alpha$ phases close to the base metal (BM). The HAZ near the FZ consists of a martensitic microstructure, resulting in higher hardness within the region than the BM. A similar phenomenon was also observed by Kabir et al. ${ }^{35}$. Similar to the FZ of AM welds, coarse columnar grains exist within the FZ of the wrought welds with an average length of 43.3 $\mu \mathrm{m}$, as shown in Fig. $8 \mathrm{c}$. The grains appear like the needle-like $\alpha$ lamellar and acicular $\alpha$,' resulting from the zone reaching the liquidus temperature and cooling at a rate above the critical cooing rate of $410{ }^{\circ} \mathrm{C} / \mathrm{s}$ as explained and also observed in ${ }^{36-38}$. The length of the columnar grains is close to that of the AM welds. 

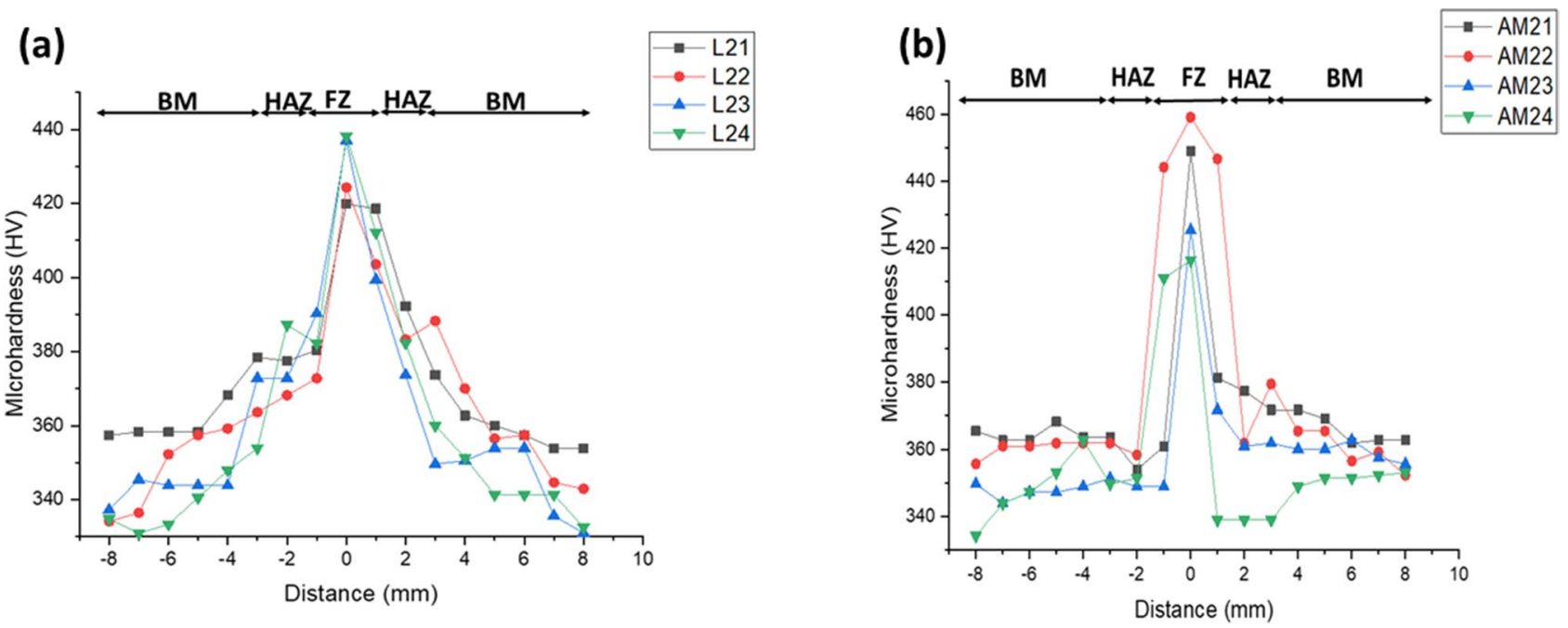

Figure 9. Microhardness profile of (a) wrought sheets welds, (b) additive manufactured product welds.
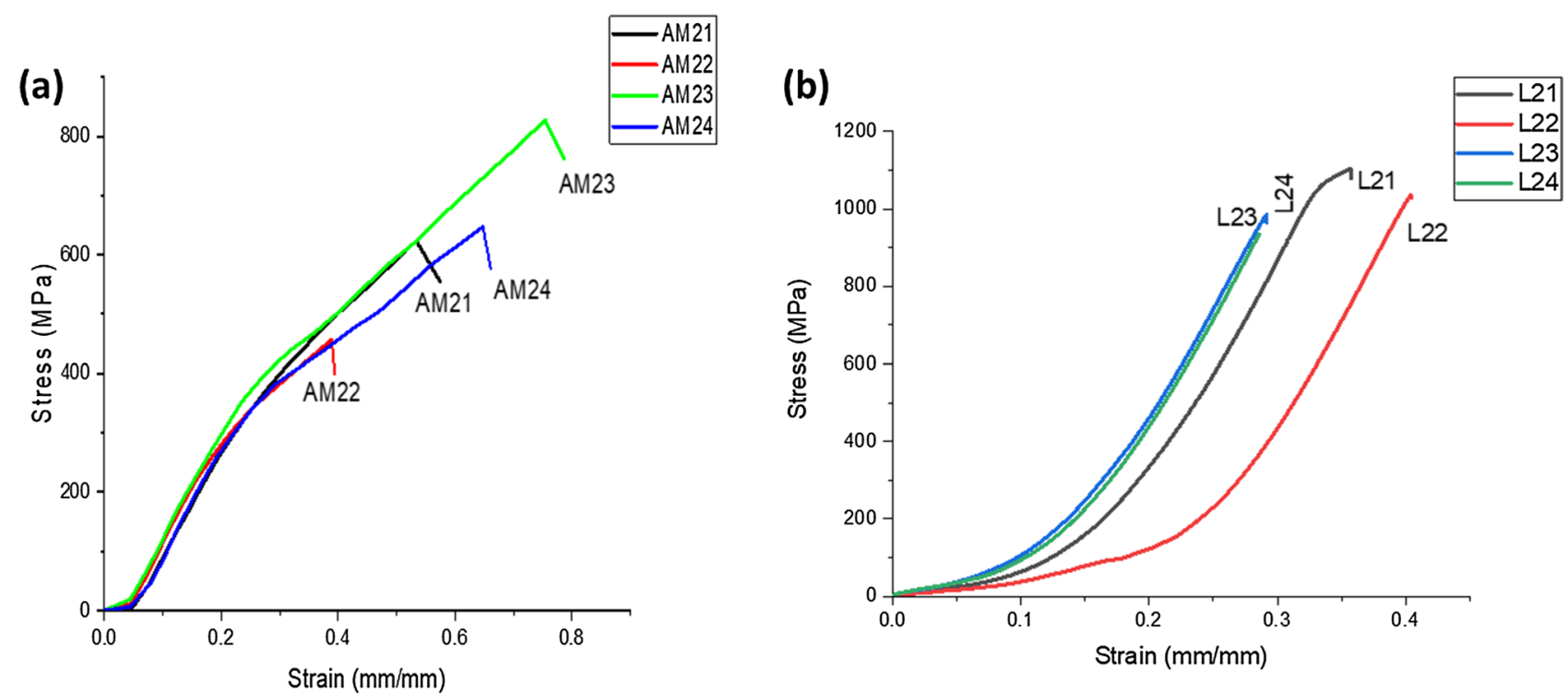

Figure 10. Stress-strain plot (a) AM welds, (b) wrought welds.

Microhardness profile. The microhardness profile is measured across the weld zone (WZ) and the base metal (BM). Each indentation was done at an interval of $1 \mathrm{~mm}$. Results of the wrought welds are shown in Fig. 9a. The FZ has the highest microhardness value ranging from 420 to $438 \mathrm{HV}$ due to the a' martensitic microstructure, which is similar to observations from ${ }^{38-41}$. Similarly, the heat affected zone (HAZ) is characterized by the coarse a' martensitic microstructure, with the microhardness ranging from 372 to $392 \mathrm{HV}$. The BM has an average microhardness value of $350 \pm 10 \mathrm{HV}$, similar to ${ }^{40-42}$ observations.

Figure $9 \mathrm{~b}$ shows the microhardness profile of the AM welds across the $\mathrm{WZ}$ and BM. Similar to the wrought welds, the FZ exhibited the highest microhardness ranging from 416 to $459 \mathrm{HV}$, followed by the HAZ with microhardness ranging from 339 to $376 \mathrm{HV}$. The BM shows relatively an almost equal microhardness value with an average value of $357 \pm 2 \mathrm{HV}$. Generally, the microhardness of the FZ and HAZ of the AM welds is higher than that of the wrought welds by an average of $8.5 \mathrm{HV}$ because of the rapid cooling of the already transformed microstructure of the AM products during laser welding. Conversely, the microhardness of the HAZ of the AM welds was reduced by an average of $24.5 \mathrm{HV}$ compared to the wrought welds. This could be attributed to the finer microstructure grains in this zone. Even though the BM's microstructure and that of the FZ are transformed to coarse columnar grains, the FZ's microhardness could be associated with the faster cooling rate experienced during laser welding compared with the cooling rate after the LMD process ${ }^{42}$.

Tensile strength analysis. The AM welds show a slight reduction in elongation compared to the parent/ base material with a tensile strength of $672 \mathrm{MPa}$. This is presumably due to the a'martensitic microstructure within the fusion zone (FZ), resulting in reduced ductility in Ti6Al4V as also observed by ${ }^{43,44}$. The maximum stress of the AM welds shown in Fig. 10a was recorded at a stress of $829 \mathrm{MPa}$ for sample AM23 welded using 

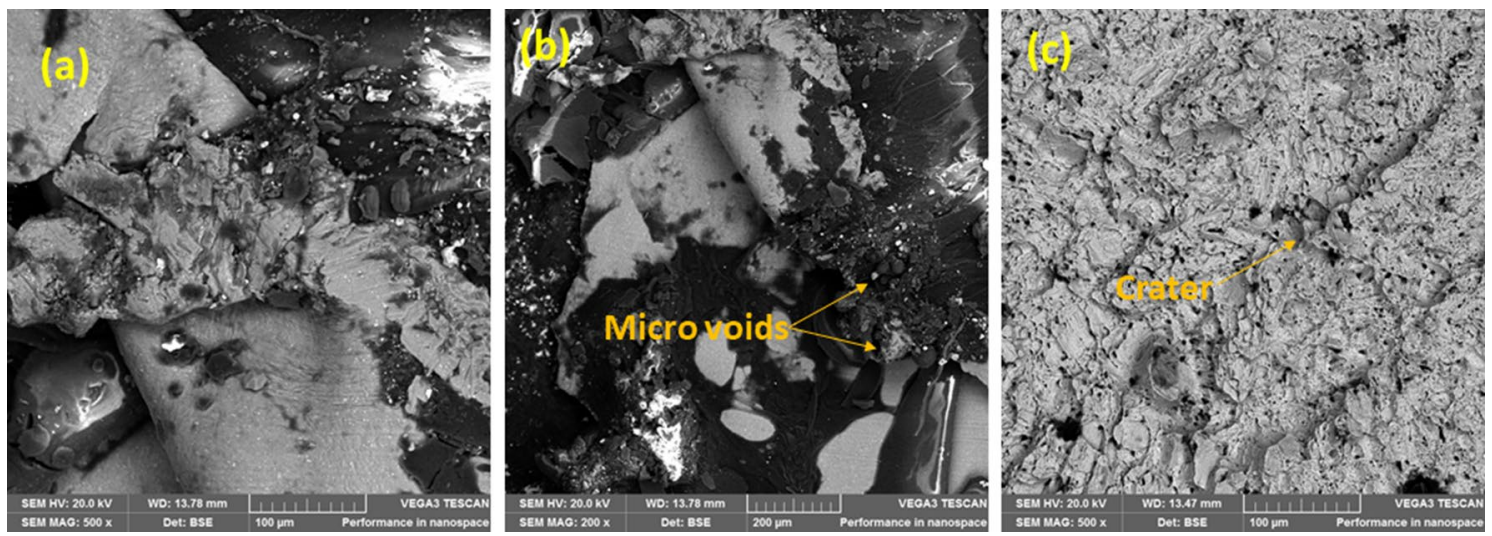

Figure 11. Fractograph of (a) LMD Ti6Al4V, (b) sample AM22, (c) sample L24.

laser power of $2.7 \mathrm{~kW}$ and welding speed of $2.8 \mathrm{~m} / \mathrm{min}$, with the lowest at $457 \mathrm{MPa}$, which was welded at a laser power of $2.8 \mathrm{~kW}$ and welding speed of $2.6 \mathrm{~m} / \mathrm{min}$. In relation to the energy input, there is an improved tensile strength with lower energy input due to a faster cooling rate, which Yung et al. ${ }^{33}$ reported to improve ductility in the weld. Compared with the wrought welds shown in Fig. 10b, there is an average of $50 \%$ reduction in ductility in the AM welds, presumably due to the high thermal stress within the FZ. Maximum stress of $1104 \mathrm{MPa}$ was recorded at a welding speed of $2.8 \mathrm{~m} / \mathrm{min}$ and laser power of $2.8 \mathrm{MPa}$ for the wrought welds. All wrought welds had a tensile strength above the base/parent material with a tensile strength of $950 \mathrm{MPa}$ except sample L24 with laser power of $2.7 \mathrm{~kW}$ and welding speed of $2.6 \mathrm{~m} / \mathrm{min}$. The wrought welds showed superior strength when compared with the AM welds.

Fractography analysis. The fractured surface of the additive manufactured product before welding is shown in Fig. 11a. The image show craters that could be presumed to result from a lack of bonding during the manufacturing process. Figure $11 \mathrm{~b}$ shows the laser welded AM product's fractured surface with a $2.6 \mathrm{~m} / \mathrm{min}$ welding speed and laser power of $2.8 \mathrm{~kW}$, which exhibited the lowest tensile strength. The presence of microvoids in this sample might have resulted in colossal stress concentration around the voids, thereby leading to failure. Figure 11c shows the fractograph of the wrought welds, which were welded using a laser power of $2.7 \mathrm{~kW}$ and a $2.6 \mathrm{~m} / \mathrm{min}$ welding speed, which exhibited the lowest tensile strength. The presence of crater and inclusions in sample L24 might have failed the material. These craters are one of the primary causes of crack propagation in materials ${ }^{45-47}$.

\section{Conclusions}

The feasibility of joining additive manufactured products manufactured through laser metal deposition (LMD) has been studied. The results evaluated show joint integrity of welded samples to be well above the parent/base material. The following conclusions are drawn:

1. Full penetration was achieved in all welds, and the bead width of the AM welds is wider than the wrought welds due to the higher thermal conductivity of the AM products.

2. The tensile strengths and ductility of the wrought welds are higher than that of the AM welds.

3. The microhardness of the AM welds is higher than the wrought welds.

4. The study shows it is possible to join AM products together with laser welding and still achieve good quality welds.

Future research will address the simulation of temperature distribution during laser welding of AM products manufactured by LMD and the effect of material thickness on the mechanical properties of the weld. Furthermore, the joining of AM products to wrought material will be assessed. Lastly, the effect of stress relieving heat treatment on the manufactured AM products will be considered.

\section{Data availability}

The data will be made available upon request.

Received: 29 October 2021; Accepted: 2 March 2022

Published online: 08 March 2022

\section{References}

1. Nahmany, M., Rosenthal, I., Benishti, I., Frage, N. \& Stern, A. Electron beam welding of AlSi10Mg workpieces produced by selected laser melting additive manufacturing technology. Addit. Manuf. 8, 63-70 (2015).

2. Omoniyi, P. O., Akinlabi, E. T. \& Mahamood, R. M. Microstructural and mechanical properties of laser deposited Ti-6Al-4V alloy: A Review. In 4th International Conference on Engineering for Sustainable World (2021). https://doi.org/10.1088/1757-899X/ 1107/1/012110. 
3. Matilainen, V. P., Pekkarinen, J. \& Salminen, A. Weldability of additive manufactured stainless steel. Phys. Procedia 83, 808-817 (2016).

4. Hassanin, A. El et al. Study of the solid state joining of additive manufactured components. In RTSI 2017-IEEE 3rd International Forum on Research and Technologies for Society and Industry, Conference Proceedings (2017). https://doi.org/10.1109/RTSI.2017. 8065967.

5. Segerstark, A., Andersson, J. \& Svensson, L.-E. Economic viability of laser metal deposition. In 6 th International Swedish Production Symposium (eds. Stahre, Johan, Johansson, Björkman, B. \& \& Mats) 1-8 (2014).

6. Azarniya, A. et al. Additive manufacturing of Ti-6Al-4V parts through laser metal deposition (LMD): Process, microstructure, and mechanical properties Additive manufacturing of Ti6Al4V parts through laser metal deposition (LMD): Process, microstructure, and mecha. J. Alloys Compd. 804, 163-191 (2019).

7. Mahamood, R. M. \& Akinlabi, E. T. Effect of scanning speed and gas flow rate on surface roughness of LMD titanium-alloy. Proc. World Congress Eng. Comput. Sci. II, 1-5 (2016).

8. Mahamood, R. M., Akinlabi, E. T., Shukla, M. \& Pityana, S. Material efficiency of laser metal deposited Ti6Al4V: Effect of laser power. Eng. Lett. 21, 1-5 (2013).

9. Omoniyi, P., Mahamood, M., Jen, T. \& Akinlabi, E. TIG welding of Ti6Al4V alloy: Microstructure, fractography, tensile and microhardness data. Data Br. 38, 107274 (2021).

10. Cheng, K., Xi, M., Chen, S., Cui, G. \& Zhou, H. Microstructures and mechanical properties of Ti6Al4V alloy repaired by the technology of point-mode forging and laser repairing. Opt. Laser Technol. 144, 107410 (2021).

11. Tavlovich, B., Shirizly, A. \& Katz, R. EBW and LBW of additive manufactured Ti6Al4V products. Weld. Res. 97, 179-190 (2018).

12. Sun, Y. Y. et al. Laser welding of electron beam melted Ti-6Al-4V to wrought Ti-6Al-4V: Effect of welding angle on microstructure and mechanical properties. J. Alloys Compd. 782, 967-972 (2019).

13. Wits, W. W. \& Jauregui Becker, J. M. Laser beam welding of titanium additive manufactured parts. Procedia CIRP 28, 70-75 (2015).

14. Omoniyi, P. O., Mahamood, R. M. \& Akinlabi, E. T. Impact of process parameters of laser welding on the mechanical properties of Ti6Al4V: A review. J. Chem. Technol. Metall. 56, 1074-1081 (2021).

15. Omoniyi, P. O. et al. Investigation of the mechanical and microstructural properties of TIG welded Ti6Al4V alloy. Adv. Mater. Sci. Eng. Select. Artic. ICMMPE 2020, 111-118 (2021).

16. Omoniyi, P. O., Akinlabi, E. T. \& Mahamood, R. M. Heat treatments of Ti6Al4V alloys for industrial applications: An overview. In 4th International Conference on Engineering for a Sustainable World (2021). https://doi.org/10.1088/1757-899X/1107/1/012094.

17. Casalino, G. \& Campanelli, S. L. Laser-arc hybrid welding of wrought to selective laser molten stainless steel. Int. J. Adv. Manuf. Technol. https://doi.org/10.1007/s00170-012-4721-z (2013).

18. ASTM B265. Standard Specification for Titanium and Titanium Alloy Strip, Sheet, and Plate. ASTM Stand. 03, 1-9 (2010).

19. ASTM B215. Standard Practices for Sampling Metal Powders. ASTM Stand. 1-7 (2015). https://doi.org/10.1520/B0215-15.1.5.

20. ASTM E3. Standard Guide for Preparation of Metallographic Specimens. Astm Int. i, (2011).

21. Standard, A. S. T. M. Standard practice for microetching metals and alloys ASTM E-407. ASTM Stand. 07, 1-22 (2016).

22. ASTM E8. Standard Test Methods for Tension Testing of Metallic Materials 1. ASTM Stand. (2016). https://doi.org/10.1520/E0008.

23. Kolhatkar, A., Karthik, V., Chaitanya, G. M. S. K., Kumar, A. \& Ramchandran, D. Development and validation of a miniature tensile specimen for determination of mechanical properties. J. Test. Eval. 47, 3417-3431 (2019).

24. ASTM E384. ASTM E384-2016: Standard Test Method for Knoop and Vickers Hardness of Materials. ASTM Stand. i, 1-43 (2016).

25. Wu, X. et al. Microstructures of laser-deposited Ti-6Al-4V. Mater. Des. 25, 137-144 (2004).

26. Todaro, C. J. et al. Grain structure control during metal 3D printing by high-intensity ultrasound. Nat. Commun. 11, 1-9 (2020).

27. Zhong, C., Liu, J., Zhao, T., Schopphoven, T. \& Fu, J. Laser metal deposition of Ti6Al4V-a brief review. Appl. Sci. 10, 1-12 (2020).

28. Kobryn, P. A. \& Semiatin, S. L. Microstructure and texture evolution during solidification processing of Ti-6Al-4V. J. Mater. Process. Technol. 135, 330-339 (2003).

29. Kelly, S. M. \& Kampe, S. L. Microstructural evolution in laser-deposited multilayer Ti-6Al-4V builds: Part I. Microstructural characterization. Metall. Mater. Trans. A 35, 1861-1867 (2004).

30. Verlinden, B., Driver, J., Samajdar, I. \& Doherty, R. Thermo-Mechanical Processing of Metallic Materials (Elsevier, New York, 2007).

31. Mahamood, R. M. \& Akinlabi, E. T. Scanning speed influence on the microstructure and micro hardness properties of titanium alloy produced by laser metal deposition process. In Materials Today: Proceedings. Vol. 4 5206-5214 (Elsevier Ltd, 2017).

32. Li, Z. et al. Reducing arc heat input and obtaining equiaxed grains by hot-wire method during arc additive manufacturing titanium alloy. Mater. Sci. Eng. A 742, 287-294 (2019).

33. Yung, W. K. C., Ralph, B., Lee, W. B. \& Fenn, R. An investigation into welding parameters affecting the tensile properties of titanium welds. J. Mater. Process. Technol. 63, 759-764 (1997).

34. Omoniyi, P. O., Akinlabi, E. T., Mahamood, R. M. \& Jen, T. C. Corrosion resistance of heat treated Ti6Al4V in NaCl. Chem. Data Collect. https://doi.org/10.1016/j.cdc.2021.100780 (2021).

35. Kabir, A. S. H. et al. Effect of welding speed and defocusing distance on the quality of laser welded Ti-6A1-4V. Mater. Sci. Technol. 4, 2787-2797 (2010).

36. Omoniyi, P. et al. Laser butt welding of thin Ti6Al4V Sheets: Effects of welding parameters. J. Compos. Sci. 5, 1-9 (2021).

37. Squillace, A., Prisco, U., Ciliberto, S. \& Astarita, A. Effect of welding parameters on morphology and mechanical properties of Ti-6Al-4V laser beam welded butt joints. J. Mater. Process. Technol. 212, 427-436 (2012).

38. Cao, X. \& Jahazi, M. Effect of welding speed on butt joint quality of Ti-6Al-4V alloy welded using a high-power Nd:YAG laser. Opt. Lasers Eng. 47, 1231-1241 (2009).

39. Liu, J., Gao, X. L., Zhang, L. J. \& Zhang, J. X. A study of fatigue damage evolution on pulsed Nd: YAG Ti6Al4V laser welded joints. Eng. Fract. Mech. 117, 84-93 (2014).

40. Kashaev, N., Ventzke, V., Fomichev, V., Fomin, F. \& Riekehr, S. Effect of Nd:YAG laser beam welding on weld morphology and mechanical properties of Ti-6Al-4V butt joints and T-joints. Opt. Lasers Eng. 86, 172-180 (2016).

41. Casalino, G., Mortello, M. \& Campanelli, S. L. Ytterbium fiber laser welding of Ti6Al4V alloy. J. Manuf. Process. 20, $250-256$ (2015).

42. Mahamood, R. M. Influence of scanning speed on microhardness property of titanium alloy. Niger. J. Technol. Dev. 13, 1-5 (2016).

43. Raju, R., Duraiselvam, M., Petley, V., Verma, S. \& Rajendran, R. Microstructural and mechanical characterization of Ti6Al4V refurbished parts obtained by laser metal deposition. Mater. Sci. Eng. A 643, 64-71 (2015).

44. Omoniyi, P. O. et al. Investigation and optimization of heat treatment process on tensile behaviour of Ti6Al4V alloy. Mater. Werkstofftech 52, 1057-1063 (2021).

45. Ikubanni, P. P., Oki, M., Adeleke, A. A. \& Omoniyi, P. O. Synthesis, physico-mechanical and microstructural characterization of Al6063/SiC/PKSA hybrid reinforced composites. Sci. Rep. https://doi.org/10.1038/s41598-021-94420-0 (2021).

46. Gao, X. L., Zhang, L. J., Liu, J. \& Zhang, J. X. Effects of weld cross-section profiles and microstructure on properties of pulsed Nd:YAG laser welding of Ti6Al4V sheet. Int. J. Adv. Manuf. Technol. 72, 895-903 (2014).

47. Gao, X. L., Zhang, L. J., Liu, J. \& Zhang, J. X. A comparative study of pulsed Nd: YAG laser welding and TIG welding of thin Ti6Al4V titanium alloy plate. Mater. Sci. Eng. A 559, 14-21 (2013). 


\section{Author contributions}

P.O., R.M., E.T., S.P., N.A., S.S., T.C.J. manuscript drafting, reviewing, S.S. Welding of materials, R.M., E.T., S.P., T.S., Y.O., M.M. conceived the research idea, P.O. carried out the experimental work, and data analysis, R.M., E.T., S.P., N.A., S.S., T.C.J., T.S., Y.O., M.M. contributed to the scientific discussions.

\section{Competing interests}

The authors declare no competing interests.

\section{Additional information}

Correspondence and requests for materials should be addressed to P.O.O.

Reprints and permissions information is available at www.nature.com/reprints.

Publisher's note Springer Nature remains neutral with regard to jurisdictional claims in published maps and institutional affiliations.

(c) (i) Open Access This article is licensed under a Creative Commons Attribution 4.0 International License, which permits use, sharing, adaptation, distribution and reproduction in any medium or format, as long as you give appropriate credit to the original author(s) and the source, provide a link to the Creative Commons licence, and indicate if changes were made. The images or other third party material in this article are included in the article's Creative Commons licence, unless indicated otherwise in a credit line to the material. If material is not included in the article's Creative Commons licence and your intended use is not permitted by statutory regulation or exceeds the permitted use, you will need to obtain permission directly from the copyright holder. To view a copy of this licence, visit http://creativecommons.org/licenses/by/4.0/.

(C) The Author(s) 2022 